\title{
KEPUASAN PASIEN PENYAKIT KRONIK TERHADAP PELAYANAN RESEP DI APOTEK DAERAH PESISIR SURABAYA
}

\author{
Oki Nugraha Putra $^{1 *}$, Ana Khusnul Faizah', Siska Dewi Fatmawati ${ }^{1}$ \\ Program Studi Farmasi, Fakultas Kedokteran, Universitas Hang Tuah Surabaya \\ Email ${ }^{1^{*}}$ : oki.nugraha@hangtuah.ac.id
}

\begin{abstract}
ABSTRAK
Apotek ialah tempat untuk melakukan pekerjaan kefarmasian dan penyaluran perbekalan farmasi kepada masyarakat. Pelayanan kefarmasian pada saat ini telah bergeser orientasinya yaitu dari drug oriented menjadi Pharmaceutical Care. Salah satu bentuk pelayanan kefarmasian di apotek ialah pelayanan resep. Penelitian ini bertujuan untuk mengevaluasi kepuasan pasien pasien penyakit kronik terhadap layanan resep di beberapa apotek daerah pesisir timur surabaya berdasarkan lima dimensi mutu pelayanan, yaitu kehandalan (reliability), ketanggapan (responsiveness), jaminan (assurance), empati (emphaty) dan keberwujudan (tangibles). Penelitian ini merupakan penelitian observasional dengan desain cross sectional menggunakan kuesioner dengan skala likert. Sampel penelitian yakni pasien dengan penyakit kronik yang memenuhi kriteria inklusi. Pasien dengan penyakit kronik dipilih secara non random dengan metode consecutive sampling. Pengambilan data dilakukan pada bulan Agustus - November 2018. Data dari kelima dimensi mutu pelayanan dianalisis dengan metode SERVQUAL. Didapatkan 100 pasien dengan penyakit kronik yang memenuhi kriteria inklusi. Hasil menunjukkan bahwa nilai rata-rata gap antara harapan dan kinerja ialah $-0,41$ dengan nilai gap terbesar ditunjukan pada dimensi reliability yaitu $-0,49$. Pada tingkat kepuasaan secara keseluruhan didapatkan hasil sebesar $89,8 \%$. Kesimpulannya ialah tingkat harapan pasien dengan penyakit kronik lebih tinggi daripada tingkat kinerja layanan resep yang diberikan oleh pihak apotek dengan tingkat kepuasaan pasien terhadap layanan resep yang tergolong baik.
\end{abstract}

Kata Kunci : Apotek, Mutu Pelayanan, Pasien penyakit kronik, SERVQUAL

\begin{abstract}
Pharmacy is a place to do pharmaceutical services. The current pharmaceutical service has shifted its orientation from drug oriented to pharmaceutical care. One of the pharmacy services is prescription service. This study aims to evaluate the satisfaction of patients with chronic disease on prescription services in several pharmacies in the east coast of Surabaya based on five dimensions of service quality, namely reliability, responsiveness, assurance, empathy and empathy and tangibles. This study is an observational study with cross sectional design and a likert scale questionnaire. The sample is patients with chronic disease who meet the inclusion criteria. Patients with chronic diseases were selected non-randomly with the consecutive sampling method. Data was collected during August until November 2018. Data from the five dimensions of service quality were analyzed using the SERVQUAL method. 100 patients with chronic disease were enrolled in this study. The results show that the average value of the gap between expectations and performance is -0.41 with the largest gap value shown in the reliability dimension which is -0.49 . At the overall satisfaction level obtained $89.8 \%$. The conclusion is the level of expectation of patients with chronic disease is higher than the level of performance of prescription services provided by the pharmacy with a relatively good level of patient satisfaction
\end{abstract}

Keywords: Patient with chronic disease, Pharmacy Service Quality (Servqual)

\section{PENDAHULUAN}

Salah satu tempat dilakukannya pelayanan kesehatan di Indonesia adalah apotek. Apotek merupakan tempat untuk melakukan pekerjaan kefarmasian dan tempat untuk penyaluran perbekalan farmasi kepada masyarakat. Pada saat ini, pelayanan kefarmasian telah bergeser orientasinya yaitu dari drug oriented ke patient oriented melalui layanan yang disebut dengan layanan kefarmasian atau pharmaceutical care. Sebagai bagian dari layanan pharmaceutical care di apotek adalah pemberian informasi, konseling dan monitoring penggunaan obat (Permenkes RI, 2016).

Salah satu bentuk pelayanan kefarmasian di apotek terdapat pada layanan resep. Adapun tujuan dari pelayanan resep ialah menjamin bahwa obat yang akan diberikan kepada pasien benar secara administratif, farmasetik, dan klinis, sehingga apoteker dituntut untuk selalu memberikan informasi obat dengan baik dan benar kepada pasien. Dengan diberikannya informasi obat kepada pasien maka masalah terkait dapat dihindari (Rantucci, 2007). Dalam melakukan pelayanan resep, maka pelayanan yang diberikan haruslah berkualitas, yang bertujuan untuk mengurangi risiko terjadinya medication error serta memberikan persepsi yang baik terhadap apotek tersebut (Harianto, 2005).

Pasien dengan penyakit kronik, pemberian edukasi terkait informasi penggunaan obat penting untuk dilakukan. Hal ini bertujuan agar pasien paham dengan terapi obat yang diberikan, sehingga akan berdampak positif pada keberhasilan terapinya. Kurangnya informasi dan pengetahuan yang baik apoteker dalam memberikan informasi obat menyebabkan ketidakpatuhan pasien untuk minum obat. 
Data Riset Kesehatan Dasar pada tahun 2013, menyebutkan bahwa data prevalensi penyakit kronik di Indonesia seperti hipertensi sebesar $26,5 \%$, penyakit jantung $2,43 \%$, dan diabetes mellitus sebesar 1,5\% (Riskesdas, 2013).

Salah satu indikator yang digunakan untuk mengevaluasi kualitas pelayanan di apotek adalah dengan mengukur tingkat kepuasan pasien. Apotek yang merupakan salah satu tempat pelayanan kesehatan sudah seharusnya melakukan pelayanan kesehatan yang memuaskan kepada pasien (Kusumawida, 2009). Berbagai kendala yang dapat menyebabkan ketidakpuasaan pasien di apotek seperti pelayanan resep yang terlalu lama, harga obat yang dianggap terlalu mahal, ketidaklengkapan obat serta ketidakramahan staf apotek (Yuniarti, 2008).

Untuk mengetahui kepuasan terhadap suatu mutu pelayanan dapat menggunakan metode SERVQUAL (service quality). SERVQUAL mengukur perbedaan antara ekspektasi pelanggan terhadap pelayanan yang dirasakan. Jika harapan lebih besar daripada kinerja, kualitas yang dirasakan kurang memuaskan dan karena itu ketidakpuasan pelanggan terjadi (Lewis, 1990). Metode SERVQUAL terdiri dari lima dimensi yaitu bukti fisik (tangible), kehandalan (reliability), ketanggapan (responsiveness), jaminan (assurance), dan kepedulian (empathy).

Berdasarkan latar belakang tersebut, dilakukan penelitian yang mengevaluasi tingkat kepuasan pasien dengan penyakit kronik terhadap pelayanan resep di apotek daerah Pesisir Timur Surabaya

\section{METODOLOGI PENELITIAN}

Penelitian ini ialah penelitian observasional dengan desain cross sectional. Alat yang digunakan pada penelitian ini ialah kuesioner dengan 15 item pernyataan yang disusun dengan skala likert, baik untuk pernyataan kinerja maupun harapan yang telah tervalidasi.. Tempat penelitian dilakukan beberapa Apotek di daerah pesisir timur, Surabaya selama bulan Juni hingga September 2018.

Sampel pada penelitian ini yaitu pasien yang menebus resep di apotek baik resep baru maupun resep ulang yang berisikan satu atau lebih obat untuk penyakit kronik (gangguan kardiovaskular, gangguan metabolik, kanker, gangguan pernafasan, gangguan saraf, dan gangguan ginjal) yang memenuhi kriteria inklusi. Kriteria inklusi pada penelitian ini ialah pasien berusia $20-70$ tahun, mampu membaca dan menulis, dan bersedia menjadi responden dengan mengisi kuesioner. Teknik pengambilan sampel menggunakan non probability sampling dengan jenis consecutive sampling yaitu setiap pasien yang memenuhi kriteria penelitian dimasukkan dalam penelitian sampai kurun waktu tertentu sehingga jumlah pasien yang diperlukan terpenuhi. Besar sampel yang diperlukan pada penelitian ini dihitung dengan rumus Lameshow (Lameshow, 2001). Dengan mensubstitusikan $\mathrm{Z}=1,96, P=0,5$ dan $\mathrm{d}=$ 0,1 , didapatkan jumlah 100 pasien.

$$
n=\frac{Z_{(1-\propto / 2)}^{2} P(1-P)}{d^{2}}
$$

Analisis kualitas layanan ditunjukan dengan kesenjangan atau gap antara nilai kinerja dan nilai harapan. Sedangkan analisis tingkat kepuasaan berdasarkan nilai korelasi tingkat kepuasaan pasien dengan cara membandingkan rata-rata nilai kinerja dan rata-rata nilai harapan.

\section{HASIL DAN PEMBAHASAN}

Pada penelitian ini diperoleh 100 pasien dengan penyakit kronik yang menebus resep di beberapa apotek daerah pesisir timur surabaya. Pada penelitian ini digunakan 5 apotek sebagai tempat pengambilan sampel. Dari 100 pasien, $47 \%$ berjenis kelamin laki-laki dan 53\% berjenis kelamin perempuan. Sedangkan untuk usia pasien, paling banyak dijumpai usia 51-60 tahun sebesar 60\%. Data demografi pasien seperti ditunjukan pada tabel 1 .

Tabel 1. Data demografi pasien dengan penyakit kronik

\begin{tabular}{ccc}
\hline Demografi & Jumlah & $\begin{array}{l}\text { Persentase } \\
(\%)\end{array}$ \\
\hline Jenis Kelamin & & \\
\hline Laki-laki & 47 & 47 \\
\hline Perempuan & 53 & 53 \\
\hline Umur (Tahun) & & \\
\hline $\mathbf{2 0 - 3 0}$ & 6 & 6 \\
\hline $\mathbf{3 1 - 4 0}$ & 9 & 9 \\
\hline $\mathbf{4 1 - 5 0}$ & 14 & 14 \\
\hline $\mathbf{5 1 - 6 0}$ & 60 & 60 \\
\hline $\mathbf{6 1 - 7 0}$ & 11 & 11 \\
\hline
\end{tabular}

Profil penyakit kronik di apotek pesisir timur surabaya seperti ditunjukan pada Tabel 2 .

Tabel 2. Profil Penyakit Kronik

$$
\text { Jenis Penyakit Persentase (\%) }
$$

\begin{tabular}{lc}
\hline Hipertensi & 53 \\
\hline Diabetes Mellitus & 25 \\
\hline Displidemia & 3 \\
\hline Hiperurisemia & 3 \\
\hline $\begin{array}{l}\text { Diabetes Mellitus + } \\
\text { Hipertensi }\end{array}$ & 9 \\
\hline $\begin{array}{l}\text { Dislipidemia } \\
\text { Hiperurisemia }\end{array}$ & 1 \\
\hline Dislipidemia + Hipertensi & 4 \\
\hline $\begin{array}{l}\text { Diabetes Mellitus } \\
\text { Dislipidemia }\end{array}$ & 2 \\
\hline
\end{tabular}


Profil Terapi Pasien Penyakit Kronik Di Apotek Pesisir Timur Surabaya seperti ditunjukan oleh Tabel 3.

Tabel 3. Profil Terapi Pasien Penyakit Kronik Di Apotek Pesisir Timur Surabaya

\begin{tabular}{lc}
\hline \multicolumn{1}{c}{ Nama Obat } & Persentase (\%) \\
\hline Amlodipin & 50 \\
\hline Metformin & 15 \\
\hline Glibenklamid & 11 \\
\hline Glimepirid & 8 \\
\hline Simvastatin & 7 \\
\hline Alupurinol & 4 \\
\hline Kaptopril & 3 \\
\hline Nifedipin & 2 \\
\hline
\end{tabular}

Hasil uji validitas kuesioner diperoleh nilai $r$ hitung pada tiap pernyataan yang lebih besar daripada $r$ tabel $(0,3610)$ dan bernilai positif, maka tiap item pernyataan tersebut telah dinyatakan valid. Pada penelitian ini juga didapatkan nilai koefisien alpha cronbach kinerja sebesar 0,759 dan untuk harapan sebear 0,759 , lebih besar dari $(\alpha=$ $0,60)$, sehingga kuesioner sudah dinyatakan reliabel. Hasil analisis gap dan tingkat kepuasaan dapat dilihat pada tabel 4 .

Tabel 4. Nilai gap dan tingkat kepuasaan layanan informasi obat menggunakan dimensi Servqual

\begin{tabular}{lcccc}
\hline Dimensi & $\begin{array}{c}\text { Rata- } \\
\text { rata } \\
\text { kinerja }\end{array}$ & $\begin{array}{c}\text { Rata- } \\
\text { rata } \\
\text { harapan }\end{array}$ & $\sum$ gap & $\begin{array}{c}\text { Kepu } \\
\text { asaan }\end{array}$ \\
\hline Reliability & 3,91 & 4,40 & $-0,49$ & 0,88 \\
\hline Assurances & 3,90 & 4,35 & $-0,45$ & 0,89 \\
\hline Tangibles & 3,78 & 4,17 & $-0,39$ & 0,90 \\
\hline Emphaty & 4,06 & 4,44 & $-0,38$ & 0,91 \\
\hline Responsiveness & 3,98 & 4,35 & $-0,37$ & 0,91 \\
\hline Rata-rata & $\mathbf{3 , 9 2}$ & $\mathbf{4 , 3 2}$ & $\mathbf{- 0 , 4 1}$ & $\mathbf{0 , 9 0}$ \\
\hline
\end{tabular}

Pasien yang melakukan pelayanan resep di beberapa Apotek daerah Pesisir Timur Surabaya didapatkan usia terbesar yaitu (51-60) tahun sebanyak (60\%). Seseorang yang berusia lebih dari 45 tahun memiliki peningkatan resiko terjadinya penyakit kronik yang disebabkan karena menurunnya beberapa fisiologis tubuh yang disebabkan pola hidup yang tidak sehat seperti kebiasaan merokok, minum minuman beralkohol, pola makan yang tiadk sehat, obesitas, kurangnya aktivitas fisik, stres, dan pencemaran lingkungan (Abdelman, 2001).

Berdasarkan analisis kepuasaan dengan metode SERVQUAL, didapatkan keseluruhan 5 dimensi dihasikan gap negatif, dimana 15 pernyataan pada kuesioner juga bernilai negatif. Berdasarkan dari tabel 4, dapat dilihat bahwa ratarata untuk nilai harapan sebesar 4,32 dan untuk nilai kinerja didapatkan 3,92, dengan nilai rata-rata gap sebesar -0,41. Dari hasil yang didapatkan, bahwa dimensi reliability memberikan nilai gap negatif yang paling besar, yaitu - 0,49 dan dimensi emphaty memberikan nilai gap negatif yang paling kecil, yakni $-0,38$. Hal ini menunjukan bahwa harapan relatif tinggi dibandingkan dengan kinerja, artinya pasien mengharapkan kualitas layanan resep untuk pasien penyakit kronik yang lebih tinggi dibandingkan dengan kinerja yang diberikan oleh apotek. Tingkat kualitas layanan pada apotek didapatkan dari persentase antara kinerja dengan harapan pada tiap dimensi. Tingkat kepuasaan pasien terbesar diberikan pada dimensi tangibles, emphaty dan responsiveness, masing-masing 91\%, tangible $90 \%$, assurances $89 \%$ dan tingkat kepuasaan paling kecil pada dimensi reliability sebesar $88 \%$. Secara keseluruhan, rata-rata untuk tingkat kepuasaan pasien yakni sebesar 89,8\% dan dikategorikan dalam kriteria sangat baik (excellent) (Arikunto, 2009).

Dimensi pertama yang dinilai adalah bukti langsung (tangibles). Pentingnya dimensi ini akan membentuk suatu image penyedia jasa dalam hal ini adalah apotek bagi pasien yang datang ke apotek (Parasurman, 1998). Pada salah satu pernyataan pada dimensi ini, yakni "Etiket rapih, jelas, mudah dibaca, kemasan menarik”, dihasikan nilai gap yang paling besar, yaitu $-0,47$. Dalam hal ini artinya bahwa pasien mengharapkan etiket yang tercantum pada kemasan obat ketika obat diserahkan kepada pasien, haruslah jelas dan mudah dipahami oleh pasien, sehingga pasien akan lebih mudah untuk mengikuti instruksi aturan minum obat.

Dimensi kedua adalah kehandalan (reliability). Pentingnya dimensi ini adalah kepuasan konsumen akan menurun bila pelayanan yang diberikan tidak sesuai dengan yang dijanjikan (tepat waktu) (Parasurman, 1998). Salah satu pernyataan pada dimensi ini ialah "Apoteker memberikan informasi tentang lama penggunaan obat", dihasilkan nilai gap yang paling besar yaitu -0,76. Hal ini menunjukan bahwa pasien mengharapkan apoteker di apotek untuk memberitahukan berapa lama obat yang diresepkan oleh dokter untuk di konsumsi. Hal ini mengingat bahwa pasien dengan penyakit kronik, diharuskan untuk mengkonsumsi obat dalam jangka waktu lama, yang kemungkinan besar dapat menimbulkan masalah pada timbulnya efek samping obat hingga ketidakpatuhan untuk minum obat.

Dimensi ketiga adalah jaminan (assurance). Pentingnya dimensi ini karena berkaitan dengan pengetahuan dan perilaku penyedia jasa untuk membangun kepercayaan dan keyakinan pada konsumen untuk menggunakan jasanya (Parasurman ,1998). Salah satu pernyataan pada dimensi ini ialah "Apoteker memiliki pengetahuan yang baik dalam memberikan pelayanan informasi obat", dihasilkan nilai gap yang paling besar yaitu 0,68 . Hal ini tentunya pasien sangat mengharapkan apoteker untuk memiliki pengetahuan yang baik 
pada saat menyampaikan informasi obat terkait resep yang didapatkan oleh pasien tersebut.

Dimensi yang keempat adalah ketanggapan (responsiveness). Pentingnya dimensi ini untuk memberikan pelayanan dengan cepat dan tanggap. Daya tanggap yang cepat dapat menumbuhkan persepsi yang positif terhadap pelayanan yang diberikan. Dimensi ini menekankan pada perhatian dan kecepatan petugas yang terlibat untuk menanggapi permintaan, pertanyaan, dan keluhan pasien (Parasurman, 1998). Pada salah satu pernyataan pada dimensi ini ialah "Apoteker bersedia menjelaskan kembali jika pasien belum paham dengan informasi obat yang diberikan", didapatkan nilai gap yang paling besar yakni $-0,41$. Hal ini artinya bahwa pasien mengharapkan bahwa apoteker senantiasa untuk menjelaskan kembali terkait terapi yang didapatkan oleh pasien jika pasien belum paham atas informasi yang diterimanya. Hal ini berkaitan dengan pemahaman informasi obat yang baik, maka pasien akan lebih patuh untuk mengkonsumsi obat, mencegah timbulnya efek samping obat yang tidak diharapkan, yang pada akhirnya akan mencapai efektifitas terapi yang diharapkan.

Dimensi yang kelima adalah kepedulian (emphaty). Pentingnya dimensi ini untuk memberikan perhatian kepada pelanggan dengan menempatkan dirinya pada situasi pelanggan (Parasurman, 1998). Pada salah satu pernyataan pada dimensi ini ialah "Apoteker memberikan perhatian terhadap keluhan yang disampaikan oleh pasien", didapatkan nilai gap yang paling besar yaitu $-0,45$. Hal ini artinya pasien mengharapkan apoteker untuk bisa memberikan perhatian lebih atas keluhan yang disampaikan oleh pasien. Keluhan bisa berupa biaya pengobatan yang terlalu mahal, kesulitan untuk mengatur jadwal minum obat, sampai dengan efek samping yang dirasakan sangat mengganggu oleh pasien. Sehingga, apoteker dapat memberikan solusi untuk keluhan terkait terapi untuk dapat memaksimalkan efektifitas terapi.

Penelitian ini sejalan dengan penelitian oleh Bertawati, yang menyebutkan bahwa tingkat kepuasan pasien terhadap pelayanan kefarmasian di Apotek sebesar 73,7\% atau pasien merasa kurang puas (Bertawati, 2013). Penelitian oleh Athiyah et al, menunjukkan bahwa pemberian informasi obat resep pada pasien Diabetes Mellitus di apotek wilayah Surabaya masih belum optimal (Athiyah et al, 2014). Hal ini menunjukkan bahwa perlu adanya perbaikan secara merata di Indonesia terkait pelayanan kefarmasian tanpa membedakan lokasi fasilitas kesehatan seperti apotek, puskesmas dan rumah sakit atau jenis pasien, apakah pasien umum atau pasien BPJS. Keterbatasan penelitian ini ialah jumlah apotek yang terbatas, yakni hanya 5 Apotek, yang kemungkinan besar belum menggambarkan secara keseluruhan hasil yang didapatkan. Selain itu pada penelitian ini juga tidak dilakukan pengukuran kepuasaan antara pasien dengan penyakit kronik yang baru menebus resep untuk pertama kalinya dan pada pasien dengan resep ulangan.

\section{SIMPULAN}

Secara keseluruhan, dapat disimpulkan bahwa kualitas pelayanan resep pada pasien dengan penyakit kronik di apotek pesisir timur surabaya informasi termasuk dalam klasifikasi gap negatif sebesar - 0,41 dengan tingkat kepuasaan pasien sebesar $89,8 \%$.

\section{SARAN}

Saran yang dapat diberikan ialah :

1. Perlu dilakukan perbaikan kinerja apotek terhadap pelayanan informasi obat pada dimensi kehandalan (reliability), ketanggapan (responsiveness), empati (emphaty), keberwujudan (tangibles) dan jaminan (assurance).

2. Dilakukan penelitian lanjutan dengan jumlah apotek yang lebih banyak agar didapatkan hasil yang lebih valid atau menggambarkan populasi secara umum

\section{DAFTAR PUSTAKA}

Arikunto, M. 2001. Manajemen Farmasi. Yogyakarta : UGM Press

Adelman, A. M., Daly, M. P., \& Weiss, B. 2001. Twenty Common problems in geriatrics. New York: McGrawHill Education

Badan Penelitian dan Pengembangan Kesehatan. 2013. Riset Kesehatan Dasar. Kementrian Kesehatan Republik Indonesia : Jakarta

Bertawati. 2013. Profil Pelayanan Kefarmasian dan Kepuasan Konsumen Apotik di Kecamatan Adiwerna Kota Tegal, Jurnal Ilmiah Mahasiswa Universitas Surabaya 2(2).

Harianto, Khasanah, N, dan Supardi, S. 2005. Kepuasan Pasien Terhadap Pelayanan Resep Di Apotek Kopkar Rumah Sakit Budhi Asih Jakarta.Majalah Ilmu Kefarmasian.

Lameshow, Stanley., 2001. Besar Sampel Dalam Penelitian Kesehatan. Gadjah Mada University, Yogyakarta

Lewis, B. R., dan Mitchell, V. W.1990. "Defining and Measuring The Quality of Customer Service," Marketing Intelligence \& Planning. Vol. 8.

Parasurman, Zeithaml, \& Berry. 1998. SERVQUAL : A Multiple Item Scale for Measuring Consumer Perceptions of Servqual quality. Journal of Retailing

Peraturan Menteri Kesehatan RI. 2016. Standar Pelayanan Kefarmasian di Apotek. Jakarta.

Kusumawida, A., 2009. Analisis Tingkat Kepuasan Pasien Rawat Jalan Askes dan Jamkesmas Terhadap Pelayanan Farmasi di Instalasi Farmasi RSUD Panembahan Senopati Bantul, Tesis, Program Pascasarjana Fakultas Farmasi Universitas Gadjah Mada, Yogyakarta 
Jurnal Penelitian Farmasi Indonesia 8(1), September 2019

Rantucci, MJ. 2007. Pharmacist Talking with Patients: A Guide to Patient Counseling, Philadelphia: Lippincott Williams \& Wilkins

Umi Athiyah et al, 2014. Profil Informasi Obat pada Pelayanan Resep Metformin dan Glibenklamid di Apotek di Wilayah Surabaya. Jurnal Farmasi Komunitas 1(1).

Yuniarti, S.D. 2008. Analisis Pelaku Pembelian Obat di Apotek dan Aplikasinya Terhadap Bauran Pemasaran Apotek Citra Graha Medika.http//www.elibrary.mb.ipc.ac.id diakses pada tanggal 20 April 2018. 